\title{
A Democracia entre Golpes e os Dilemas da Esquerda (1975-1976)
}

\author{
The Democracy between Putsches and the Dilemmas of the Left (1975-1976)
}

\author{
Eurelino Coelho* \\ Universidade Estadual de Feira de Santana (UEFS), Feira de Santana, BA, Brasil
}

\begin{abstract}
RESUMO: Em face da política de distensão anunciada pela alta cúpula do poder executivo brasileiro a partir de 1974 e diante do fracasso da luta armada, ganhou urgência entre as organizaçóes de esquerda a reavaliação das formas de enfrentamento da ditadura e, para a maioria delas, do significado da democracia para aqueles que continuavam a lutar pelo socialismo. Este artigo analisa o debate aberto no interior da Tendência Proletária (TP), uma articulação que organizações e militantes de esquerda brasileiros tentaram construir em meados da década de 1970 e que teve na revista Brasil Socialista sua expressão pública mais conhecida. A ácida polêmica, cuja intensidade levou à ruptura da composição inicial da TP, mobilizou um rico repertório de argumentos a partir dos quais é possível observar as distintas abordagens do tema da democracia na esquerda marxista, bem como algumas questóes a respeito da fragilidade duradoura da democracia no Brasil.
\end{abstract}

PALAVRAS-CHAVE: Brasil. Ditadura militar. Partidos e organizaçóes de esquerda. Democracia.

\begin{abstract}
The distension politics announced by the leader of Brazilian government since 1974, and the failure of the armed struggle, became urgent for left-wing organizations to re-evaluate both the ways to fight against the dictatorship and, for most of them, the meaning of democracy assumed for those who still fighting for socialism. This article analyses the debate within the Tendência Proletária (TP), an articulation that leftist Brazilian organizations and militants tried to construct in the middle of the decade of the 70 and that had in the Brasil Socialista magazine its most known public expression. The rough polemic, whose intensity led to the rupture of the initial composition of TP, mobilized a rich repertoire of arguments from which it is possible to observe the different approaches to the theme of democracy between Marxists militants as well as some questions about the lasting fragility of democracy in Brazil.
\end{abstract}

KEYWORDS: Brasil. Military dictatorship. Leftists parties and organizations. Democracy.

\footnotetext{
* Professor da Universidade Estadual de Feira de Santana (UEFS), Feira de Santana, BA, Brasil. Doutor em História pela Universidade Federal Fluminense (UFF).E-mail: eurecoelho@uefs.br. https://orcid.org/0000-0002-2655-0225.
} 
Mais um golpe, mais ameaças! A história da democracia no Brasil parece mesmo ser a história de sua instabilidade incurável. Sérgio Buarque de Holanda talvez não imaginasse que sua boutade descreveria não apenas a política das velhas oligarquias sobreviventes do passado, mas também a da moderna burguesia que vem dirigindo o futuro. Em todo caso, é difícil negar, a democracia por aqui continuou sendo um lamentável mal-entendido (HOLANDA, 1984). Entre 1936, quando Sérgio Buarque publicou sua obra-prima, e 2016, foram oitenta anos em que o Brasil passou por enormes e profundas mudanças que afetaram todos os espaços da vida nacional, mas o aparato institucional de dominação política, que também se modificou muito, cambaleou e rachou várias vezes e continua, ainda hoje, vulnerável. Seu poder repressivo, seletivamente voltado contra os grupos sociais subalternos, manteve-se sempre robusto, mesmo com as mudanças, porém seu aparelho processador da vontade política dos grupos dominantes emperrou e teve de ser violentamente substituído em muitas ocasióes. Em diferentes momentos, por perspectivas distintas nem sempre complementares, autores como Santos (1970), Fernandes (1975), Vianna (1976) e Fontes (2010), dentre outros, estudaram em profundidade este problema.

Esta é uma das razóes pelas quais o item democracia se manteve em caixa-alta na agenda das organizaçóes de esquerda no Brasil. Lendo a documentação produzida por grupos de esquerda por várias décadas, vemos que suas pautas nunca deixaram de incluir, com impressionante regularidade, problemas teóricos e práticos decorrentes da fragilidade genética da democracia a respeito dos quais proliferaram mais dissensos que consensos: caracterização de governos golpistas, formas de luta contra as ditaduras, construção de táticas para a atuação sob regimes de exceção, ligações entre a estratégia socialista e os problemas imediatos decorrentes da supressão de liberdades e direitos. Os artigos reunidos por Ferreira e Reis (2007) permitem observar a persistência dessa temática ao longo de mais de um século de história das esquerdas no Brasil.

As linhas a seguir nasceram de um estudo sobre como certas organizaçóes de esquerda travaram, nos anos centrais da década de 1970, um intenso debate a respeito de questóes conectadas, de alguma maneira, ao tema da democracia. O golpe de 1964 já não era recente e o regime nascido dele emitia sinais de que algo estava para mudar. Investigamos documentos produzidos por dirigentes de três grupos políticos: a Ação Popular Marxista-Leninista (APML), o Movimento Revolucionário 8 de Outubro (MR-8) e a Organização de Combate Marxista-Leninista Política Operária (OCML-PO). Em 1975, avançava um movimento de aproximação entre essas organizaçóes, a partir de iniciativas de alguns membros de suas direções que se encontravam no exílio. Os que estiveram envolvidos naquela tentativa falavam em construir a Tendência Proletária da esquerda brasileira, orientada pelo marxismo-leninismo, cujos princípios envolviam caracterizar o Brasil como sociedade capitalista dependente e lutar por uma revolução de caráter socialista que teria o proletariado industrial como força hegemônica (BRASIL SOCIALISTA, 1975). Nasceu deste esforço a revista Brasil Socialista, editada no exterior e com alguma circulação nas esferas dirigentes de grupos de esquerda no Brasil, da qual foram publicados oito números entre janeiro de 1975 e janeiro de 1977 . A base de nosso corpus foi extraída dessa revista ${ }^{1}$ e de alguns outros documentos que, publicados à parte, referem-se explicitamente às polêmicas abertas em suas páginas. Selecionei somente textos em que são tratadas questôes direta ou indiretamente ligadas à temática geral da democracia.

É um rico debate, como o leitor verá, e, para as organizações mencionadas, relativamente pouco estudado. Mario Grabois, que pesquisou um conjunto bem mais amplo e diversificado de organizações de esquerda (ele usa o termo “esquerda revolucionária”) envolvidas nos embates sobre a questão democrática, considera que 
[...] um dos aspectos mais importantes ocorridos entre os comunistas brasileiros nos anos 70, talvez o mais importante, seja justamente o debate sobre democracia, o papel desempenhado pela classe operária e o povo na luta democrática e a sua relação com o socialismo, articulado às definições táticas do combate pelo fim da ditadura. (GRABOIS, 2007, p. 56)

Minha escolha foi desistir da grande amplitude adotada por Grabois em troca da oportunidade de ir mais fundo na investigação de apenas um dos grupamentos de esquerda revolucionária em ação naqueles anos, a Tendência Proletária. À limitação da abrangência correspondeu o crescimento vertical do corpus, o que nos permitiu conhecer a profundidade e a sofisticação que marcaram a elaboração teórica daquelas organizaçóes, mas também seus limites e dificuldades para superar diferenças.

Eduardo Stotz (2010) recuperou as diferentes linhas de interpretação da ditadura traçadas pela esquerda marxista brasileira e, num segundo momento, as alternativas de tática na luta contra o regime militar. Apesar de sua atenção ao mapeamento das diferenças entre as posições dos grupos de esquerda, ele não teve como se aprofundar em nenhum momento específico daquelas polêmicas ou na observação mais específica da Tendência Proletária.

Rosalba Lopes, em artigo de 2013, também estudou o debate sobre democracia na experiência de construção da Tendência Proletária, sustentando a hipótese de que a transformação vivida pelas esquerdas com a derrota da luta armada teria levado a uma "inflexão democrática no pensamento da esquerda brasileira” que envolvia tanto a "[...] superação de elementos autoritários, quanto a incorporação de valores democráticos, ainda que o processo não tenha atingido igual profundidade em todas as organizações" (LOPES, 2013, p. 101). O núcleo dessa inflexão teria sido a "autocrítica” dos "elementos autoritários da cultura política da esquerda marxista brasileira”, com destaque para o "forte teor vanguardista” presente nas formulações teóricas. Daquela autocrítica resultou a "[...] mudança nos padrões de relacionamento com a sociedade que pretendiam revolucionar [...]” e a construção dos "[...] espaços que propiciarão um rico encontro entre tais organizações políticas e os setores organizados da sociedade” (LOPES, 2013, p. 102). Minhas investigações confirmam a existência de críticas ao vanguardismo incorporadas à discussão política geral daquelas organizações em 1975 e 1976, mas nem todas elas seguem na direção imaginada por Lopes. Além do mais, o acerto de contas com o vanguardismo da esquerda ou com os "elementos autoritários" de sua cultura política não teve correspondência direta com seu eventual "encontro" com "setores organizados da sociedade” nem, muito menos, da classe trabalhadora. $\mathrm{O}$ argumento é quebrado pelas trajetórias posteriores de MR-8 e OCML-PO em meio à maré montante de lutas dos trabalhadores e às cristalizaçóes organizativas que ela proporcionou (Partido dos Trabalhadores, Central Única dos Trabalhadores, Movimento dos Trabalhadores Rurais Sem Terra): o primeiro que, segundo Lopes, teria avançado mais na "autocrítica”, manteve-se à margem das novas organizações de massas, enquanto o grupo acusado de perseverar no doutrinarismo autoritário se incorporou e vários de seus militantes terminaram guindados a posiçôes dirigentes.

A construção da Tendência Proletária, nos termos inicialmente propostos, terminou fracassando e um dos pontos de atrito mais intenso foi exatamente o tema da democracia. O conteúdo das polêmicas não se limita a questôes de natureza conceitual ou abstrata, embora elas sejam onipresentes. A elas se articulam as considerações de problemas políticos de natureza prática, delineados a partir de análises de uma conjuntura especialmente desafiadora - os anos iniciais do governo Geisel. Aqueles militantes da APML, do MR-8 e da OCML-PO que se dedicaram a reconhecer o 
cenário, interpretá-lo a partir dos recursos teóricos do marxismo e traçar cursos de ação não tinham como fugir da esfinge da democracia burguesa no Brasil e de seus enigmas. Conhecer a história de suas tentativas, de seus avanços e desencontros, foi o que se buscou aqui. Se a frase de Sérgio Buarque de Holanda ainda tiver validade, como acredito, pode ser que essa história nos ajude a formular perguntas sobre os dilemas de quem luta por mudanças radicais num ambiente em que perduram as formas não apenas limitadas, mas quebradiças de democracia.

\section{Tendência Proletária: por uma política revolucionária contra a ditadura}

Quando foi publicado o primeiro número de Brasil Socialista, o general Ernesto Geisel estava prestes a completar seu primeiro ano à frente do governo militar. Discursos proferidos por ele desde antes da posse, que ocorreu em março de 1974, emitiram sinais de que alguma mudança estava em gestação nos gabinetes da cúpula do regime. Na primeira reunião com seu ministério, em dezenove de março de 1974, o Presidente comprometia-se com "[...] sinceros esforços para o gradual, mas seguro, aperfeiçoamento democrático, [...] para a criação de um clima salutar de consenso básico e a institucionalização acabada dos princípios da Revolução de 64". Chegava a mencionar, mesmo que obliquamente, a possibilidade de substituir os instrumentos "excepcionais" de poder (dos quais o AI-5 era o mais emblemático) por "salvaguardas constitucionais", desde que fossem eficientes (GEISEL, 2018, s. p.).

Por outro lado, a luta armada na modalidade de guerra de guerrilha, era, em 1975, uma página virada para os editores da revista. As experiências de cada organização com a guerrilha tinham sido bem diferentes, mas todas elas agora faziam duras críticas ao "desvio militarista", cujo fracasso custara caro demais aos socialistas. A APML e o MR-8, cujo envolvimento com a luta armada tinha sido muito mais intenso, incluíram a autocrítica daquela experiência nos movimentos que as tinham conduzido em direção à Tendência Proletária. No caso da APML, o caminho foi aberto a partir da intensa luta interna que levou a maioria da organização a ingressar no Partido Comunista do Brasil (PCdoB) em maio de 1973. A minoria que se opôs à incorporação e manteve o nome APML, sofreu, no mesmo período, perdas de vários dirigentes ceifados pela repressão e, muito debilitados, reelaborou profundamente sua linha política: o Brasil é um país capitalista dependente (e não semifeudal), o caráter da revolução brasileira é socialista, seu dirigente será a classe operária e a forma prioritária de luta não será a guerrilha rural ou urbana, mas a insurreição dos trabalhadores nas cidades (DIAS, 2004; OLIVEIRA JUNIOR, 2000).

Por outras vias, o MR-8 tinha chegado às mesmas posições. Em janeiro de 1971, embora as atividades armadas prosseguissem, uma crítica ao foquismo por seu caráter voluntarista e espontaneísta já aparece no documento Orientação Para a Prática (MR-8, 1971). O debate interno após a morte de Lamarca, em setembro de 1971, aprofundou a crítica ao militarismo e ao distanciamento que ele impôs entre uma organização que luta pela revolução e as massas operárias. Diferentemente da APML, o Oito já orientava, pelo menos desde 1969, sua linha política para um processo revolucionário caracterizado como socialista, já que a

[...] contradição principal na sociedade brasileira é a que opõe o proletariado à burguesia, compreendendo esta como resultado de um processo de integração/dependência entre o imperialismo e a burguesia local. Nesta medida, destruir o imperialismo significa necessariamente destruir a burguesia local e vice-versa. (MR-8, 1985, p. 344) 
Em dezembro de 1972, reuniu-se o Pleno, instância deliberativa superior, que aprofundou e consolidou a autocrítica e reafirmou princípios programáticos em bases semelhantes àquelas que a APML construiria no ano seguinte.

Tais princípios eram muito próximos daqueles que vinham sendo postulados pela Organização Revolucionária Marxista Política Operária (ORM-PO, também chamada de POLOP) desde seu surgimento, em 1961, e foi com base nessa proximidade que a articulação da Tendência Proletária foi tentada mais tarde. Quando a luta interna cortou a meio a POLOP, em 1967, o grupo dos militantes alinhados com a direção nacional aproximou-se de outros coletivos (o mais importante foi a Dissidência Leninista, egressa do PCB no Rio Grande do Sul) e fundou o Partido Operário Comunista - POC. Pouco tempo depois, em 1970, o POC também rachou e a maioria dos militantes oriundos da antiga POLOP saiu para construir a OCML-PO (BRITO, 2016). A luta armada, na forma de guerrilha, tinha sido incorporada ao programa da POLOP desde os anos 1960, e constava no Programa Socialista para o Brasil, documento de 1967 que foi adotado pelo POC e também pela OCML como referência máxima. Não houve, no entanto, experiência concreta da organização com a luta armada (exceto por iniciativas tímidas e rapidamente descontinuadas ainda em meados da década de 1960). De qualquer modo, a crítica à guerrilha, denunciada como voluntarismo pequeno-burguês, subiu de tom e radicalizou-se no início dos anos 1970 (COELHO, 2014).

As três organizações envolvidas na construção da Tendência Proletária partiam, então, de referências programáticas semelhantes quando se propuseram a discutir as bases de sua ação política conjunta. A crítica à opção guerrilheira punha na ordem do dia a discussão de alternativas táticas para a ação política imediata, tarefa a ser enfrentada com outras armas que não as de fogo. Qualquer política a ser feita, além disso, teria de defrontar-se contra uma ditadura militar em tempos de "institucionalização" e "distensão".

Com cauteloso otimismo, os editores de Brasil Socialista observavam as frestas que apareciam. Raul Villa, que atuou como representante da OCML-PO junto à revista na fase inicial, escreveu, no primeiro número (janeiro de 1975): "A ditadura militar enfrenta agora os efeitos sociais da recessão econômica sem ter logrado criar, durante a expansão, nem mecanismos institucionais para resolver disputas nas classes dominantes, nem base de apoio e legitimação ideológica mais sólida” (VILLA, 1975, p. 4). Villa menciona alguns focos de insatisfação entre cafeicultores, na FIESP (Federação das Indústrias do Estado de São Paulo) e até em setores bancários que, ao ganharem visibilidade na grande imprensa, mostram que também ela acumula diferenças com o governo. A expectativa de uma "abertura” era uma resposta a essas inquietações, mas a tática de Geisel (e de seu braço direito, Golbery) envolvia também o "[...] velho estilo de assustar a oposição apontando para um perigo ainda mais à direita.” (Idem, Ibidem, p. 8). A “distensão” era projetada para correr sob estrito controle de Brasília.

Villa escreve antes de conhecer os resultados da "farsa eleitoral" de 1974 - a OCML havia defendido o voto nulo naquele pleito - e toca num ponto extremamente sensível. Seu argumento é que o provável aumento de votos dados à "oposição consentida" não poderia ser interpretado como o "[...] que determinará as condições de uma nova conjuntura na luta de classes no país. É esta, pelo contrário, que se exprime parcial e deformadamente nos votos ao MDB [...]”, cuja direção se empenha em barganhar com os militares sem assustá-los, assumindo o lugar de "oposição leal" (Idem, Ibidem, p. 13). Seria um equívoco recomendar o apoio ao Movimento Democrático Brasileiro (MDB), partido legal de oposição, como arma contra a suposta "fascistização" do regime, 
como fazia o Partido Comunista Brasileiro (PCB), pois acreditar que o MDB “[...] vai se opor à ditadura, trata-se de um engano que o próprio MDB apressa-se a desmentir”. Se, por outro lado, trata-se de alertar contra o risco de algo "ainda mais à direita”, então as fichas são postas “dentro das opções legítimas para o sistema. Mas não para o proletariado” (Idem, Ibidem, p. 13).

Qual rumo deveria tomar, neste cenário, a esquerda revolucionária? Em seu artigo, que não tratava propriamente dessa questão, Villa não vai além de indicações genéricas: “[...] tornar-se verdadeiramente proletária [...] uma força política tendo por núcleo os polos mais avançados da classe operária; com um programa de classe contra a ditadura militar, capaz de atrair as massas populares para a perspectiva revolucionária do proletariado [...]” (Idem, Ibidem, p. 14).

No editorial de seu segundo número, publicado em abril de 1975, Brasil Socialista constatava outras evidências de fissuras no bloco das classes dominantes, com tendências ao enfraquecimento da ditadura. Através de seus "mais lúcidos porta-vozes civis e militares" a grande burguesia industrial e financeira “[...] mostra estar ciente de que não poderia enfrentar a nova situação e absorver os interesses contraditórios que vem aflorando com um esquema político como o que vigorou no período Médici, demasiadamente centralizado e rígido". Nasce daí o processo de "institucionalização" ou "descompressão gradual” do regime (BRASIL SOCIALISTA, 1975b, p. 3). O cenário seria composto também pela paulatina reanimação do movimento popular de que eram indicadores a votação maciça obtida pelo $\mathrm{MDB}$ em bairros pobres e habitados por famílias de trabalhadores, a lenta retomada da atividade sindical, lutas populares em bairros e por transportes, alguns sinais de atividade no meio estudantil e persistência de conflitos no campo, embora localizados.

O editorial sublinha que nada disso estaria ainda consolidado, já que eram apenas elementos tendenciais de uma conjuntura em suas tímidas etapas iniciais. Mesmo assim o quadro é visto como "bastante mais favorável para as lutas da classe operária e do povo, para a ampliação da resistência à ditadura militar e para a reconstrução da esquerda revolucionária em torno de uma perspectiva proletária.” A “[...] grande burguesia industrial e financeira - intimamente associadas ao imperialismo - encontrará dificuldades sérias para o exercício de sua hegemonia [...]” e, com isso, o movimento operário e popular “[...] poderá converter-se num fator político de grande peso” (Idem, Ibidem, p. 2). Responder à conjuntura exigiria aperfeiçoar a tática, e o editorial esboça o mapa das tarefas que consistem em

[...] aprofundar o isolamento da ditadura militar, impedindo sua institucionalização; em desmascarar e deslocar do centro da oposição a média burguesia, neutralizando sua política moderada; em atrair a pequena burguesia democrática, levando-a a ultrapassar suas posiçóes 'redemocratizadoras'; em unir o conjunto das massas trabalhadores em torno da classe operária, ampliando e organizando sua resistência, na luta pelas liberdades democráticas e em defesa de seu nível de vida, fazendo-as convergir para a derrubada da ditadura militar e a liquidação de suas bases de sustentação. (BRASIL SOCIALISTA, 1975b, p. 3)

Explorar por esse ângulo a relevância política da classe trabalhadora foi o fio com o qual os editores procuraram tecer sua política de enfrentamento à ditadura, tal como rascunhada acima pelo editorial, mas com o mesmo fio era tecido o pavio que levaria, em pouco tempo, à implosão da Tendência Proletária. Isso, porém, permanecia quase invisível para os leitores de Brasil Socialista, em abril de 1975. 
O resultado das eleições de novembro de 1974 já era conhecido quando a edição de abril foi fechada e o tema ganhou espaço na revista em três textos, dois dos quais oriundos da APML. O artigo de Fábio de Almeida, codinome de Ricardo Azevedo, é um balanço dos resultados: vitória do $\mathrm{MDB}$ no senado, com treze milhões de votos contra 7,5 da governista ARENA (Aliança Renovadora Nacional) e dezesseis senadores eleitos, além de votação maciça em cidades industriais e bairros operários significariam que o

[...] MDB conseguiu atrair para si os votos do proletariado urbano e rural, dos 'pobres da cidade', da maior parte da pequena burguesia urbana e rural, de setores importantes da média burguesia industrial e agrária e de alguns setores da burguesia industrial e financeira e da burguesia agrária do centro-sul. (ALMEIDA, 1975, p. 5)

Almeida olha com atenção a votação significativa recebida pelo grupo "autênticos” do MDB, votos que "[...] expressam os setores mais avançados do proletariado e os setores radicalizados da pequena burguesia democrática [...]" (Idem, Ibidem, p. 10) que veem na ditadura seu inimigo principal. Enfatizando na campanha a luta pela redemocratização, os “autênticos” atraíram o apoio até mesmo de setores da esquerda revolucionária, que emergia debilitada da derrota da luta armada, enfraquecendo a denúncia da "farsa eleitoral" e a campanha pelo voto nulo.

Aqueles eram argumentos voltados para disputas com outros setores da Tendência Proletária, como ficaria evidente depois. Do ponto de vista das classes dominantes, segundo Almeida (1975), a vitória do MDB reforçava a convicção da necesidade de avançar no caminho da "institucionalização do regime de exceção", visando a garantir que o "[...] movimento popular se expresse sob controle [...] " e “[...] neutralizar determinados setores de oposição como a Igreja e intelectuais" (Idem, Ibidem, p. 13). No entanto, este quadro poderia ser alterado por movimentos de massas, a ponto de se inviabilizar o projeto de "institucionalização" bancado por Geisel e apoiado pelo MDB. "Nessa conjuntura”, conclui Almeida, cabe à

[...] esquerda proletária lançar um programa tático, tendo como eixo a luta por liberdades democráticas, que lhe permita aprofundar sua ligação com o movimento de massas, canalizando para o movimento operário o centro da oposição à ditadura, atraindo em torno dele e de seu programa a pequena burguesia democrática, os setores progressistas da Igreja e da intelectualidade e os "autênticos radicais" do MDB [...] acirrando portanto as contradiçóes no seio das classes dominantes e no interior do $\mathrm{MDB}$, desmascarando o projeto de institucionalização da ditadura e a inconsequência da oposição burguesa. (ALMEIDA, 1975, p. 17)

O outro texto da APML publicado naquele número foi um documento aprovado pela organização ainda antes das eleições, em outubro de 1974, que indicava a política a adotar diante da "farsa eleitoral". Com abundantes citações de Lenin, o texto reconhece que eleições são um problema de tática, não de estratégia - o que significa que os marxistas não devem ter qualquer posição de princípio a respeito de participar ou não delas. Mas, citando a mesma autoridade, o texto insiste na importância da tática para as organizações revolucionárias, já que a construção do partido revolucionário, objetivo prioritário, não pode se dar somente com formação teórica geral baseada no "programa máximo", porém também com a formação pela prática de intervenção na conjuntura, isto é, pela agitação política. A qualquer organização que não estiver munida dessa orientação tática só restaria 
[...] viver à margem do movimento real da luta de classes fazendo uma pregação de natureza estratégica que se perderá no vazio. Ao tentar mobilizar as massas diretamente em torno do programa estratégico, descobrirá (como repetidas vezes já ocorreu em nosso país e no exterior) que sua política só era compreensível e praticável por uma pequena e restrita elite de 'iniciados'. (APML, 1975, p. 55)

O envolvimento na luta de classes do presente, polarizada pelo combate à ditadura, era o espaço possível para a construção do partido revolucionário, desde que orientada por uma tática que não se confundisse com a "[...] volta à ditadura disfarçada da burguesia, através da conquista da 'democracia' com um governo civil burguês.” A posição da APML é expressa em itálico no documento: é "[...] justa a luta pela ampliação da resistência dos trabalhadores à ditadura militar, tendo como eixo central a luta por liberdades democráticas". Tal ampliação não significaria, "absolutamente", lutar por um governo burguês democrático. Trata-se de "[...] acumular forças para, conquistando tal objetivo, estarmos em melhores condições de intervenção na luta de classes” (Idem, Ibidem, p. 56, grifos do autor).

Estabelecidas as premissas, o documento pode agora dar seu passo decisivo: liberdades democráticas interessam a outras classes, além do proletariado, o que exige pôr em discussão o problema das alianças que podem e devem ser feitas em torno desse objetivo. A pequena burguesia urbana, sobretudo, tem interesse e "[...] tem dado mostras, de 1964 para cá, do quanto é capaz de participar dessa luta”. Trata-se de “[...] aliança de ordem tática, temporária e passageira, que não se confunde com a aliança básica que a classe estabelece do ponto de vista estratégico”. O cuidado precisaria ser o de estabelecer os pontos essenciais, a respeito dos quais não poderia haver concessóes: seriam inadmissíveis acordos com quaisquer "[...] restrições à independência ideológica-política do proletariado, ou que o levasse a renunciar a suas lutas contra a burguesia" (Idem, Ibidem, p. 57). Posto isso, a hegemonia na frente política não poderia ser estabelecida de antemão em favor do proletariado, teria de ser disputada politicamente.

Com base nesta elaboração tática, a APML definia sua política para as eleições de 1974: “[...] ao lado da posição de voto nulo e em branco, abrir a alternativa de que podemos vir a apoiar algum candidato que preencha os requisitos mínimos para tal" (Idem, Ibidem, p. 62). Uma série de exigências teria de ser aceita pelo candidato para receber o apoio: “[...] entrar efetivamente na denúncia da ditadura militar, no enfrentamento real de sua sanha repressiva e no desnudamento do papel de classe que desempenha [...]" como servidora não somente do imperialismo, mas também da burguesia brasileira, denunciar "assassinatos políticos, as torturas e os torturadores", a artificialidade dos dois partidos e sua "inteira falta de representação real" (Idem, Ibidem, p. 63). Sobre esta base seria possível a aliança com candidatos da ala dos "autênticos” do MDB que representam justamente a pequena burguesia urbana democrática e radicalizada, caracterizada na reflexão sobre a tática.

A APML já sabia, ao escrever seu documento, que aquela era uma proposta que enfrentaria dura oposição no interior da Tendência Proletária por parte de segmentos que defendiam que se mantivesse em 1974 a mesma posição que todas tiveram em 1970, a saber, o voto nulo. Toda a ênfase no problema da tática cumpria também o papel de criticar, sem nomear o alvo da crítica, a "pregação no vazio" e o distanciamento do "movimento real da luta" que caracterizariam outra corrente da Tendência Proletária. Esta corrente, que também era a mais intransigente defensora do voto nulo em 1974, era a OCML-PO que publicava, no mesmo número da revista, sua análise de conjuntura escrita também antes das eleições. 
“A paz no bloco do poder foi quebrada” (POLÍTICA OPERÁRIA, 1975, p. 66): este é o ponto de partida da análise da conjuntura da OCML, afinada com outras interpretaçóes publicadas por Brasil Socialista na constatação de que a crise econômica trincava as bases políticas da unidade entre setores das classes dominantes. Se a constatação era coincidente, a interpretação nem tanto. O cenário construído em 1968 ter-se-ia modificado em função do reposicionamento de grupos burgueses, mas, com a perda de fôlego da ditadura, o "[...] único movimento capaz de se impor a prazo como resposta das classes dominantes à crise nacional, é o movimento pela redemocratização, único capaz de polarizar novas forças em torno de um governo burguês" (Idem, Ibidem, p. 67). A identificação do caráter burguês do movimento pela redemocratização tem, como veremos, consequências sérias na análise da OCML.

Do lado dos trabalhadores, apesar de alguns sinais positivos provenientes de agitaçóes operárias, por transporte ou do movimento estudantil, a avaliação era de que o movimento ainda não teria superado os limites postos desde 1968: dispersão e fragmentação de lutas, separação entre vanguardas e massas. Sob tais condições, a reaparição do movimento de massas tenderia a adquirir feições populistas, com direção pequeno-burguesa. Viabilizar uma alternativa depende da criação de "[...] uma força proletária de luta, dependendo da atividade da esquerda proletária pela introdução de métodos e objetivos proletários nas lutas de massa [...]” apta a canalizar “[...] pela formação de uma força revolucionária, independente e socialista, o imenso potencial destrutivo que este movimento em breve revelará” (Idem, Ibidem, p. 67). A Tendência Proletária, constituída com base na afinidade com as teses que a POLOP via como suas, era, ela mesma, a busca dessa alternativa, mas o perigo rondava. É que

[...] grande parte da esquerda revolucionária [...] embarca agora no movimento pela redemocratização. Este lamentável espetáculo revela, de um lado, a reafirmação das estratégias claramente reformistas e populistas e, de outro, indica que as forças que realmente evoluíram no sentido de posições proletárias, apenas mantém os olhos voltados para os horizontes proletários, enquanto continuam com os pés presos no pântano pequeno-burguês. Este desvio tem que ser combatido com a mesma violência como combatemos o militarismo. (POLÍTICA OPERÁRIA, 1975, p. 67-68)

Estavam postos os termos iniciais do debate entre os coletivos da Tendência Proletária. O tema da democracia coloria o fundo do cenário em que eram discutidas as alternativas de enfrentamento à ditadura militar, porque tais alternativas envolviam, necessariamente, tomar posição diante da bandeira pela redemocratização que, mais cedo do que tarde, seria empunhada em público por agentes políticos relevantes. Como interpretar, do ponto de vista da luta de classes, a luta pela redemocratização? O modo como a questão fosse formulada e respondida demarcaria posições no campo da esquerda revolucionária, e bastava enunciá-la para desencadear uma sequência de outras: sobre as bases de classe do regime militar, dos setores dissidentes e das oposiçóes, sobre a conexão entre tática e estratégia revolucionária, entre a luta contra a ditadura e a luta pelo socialismo, sobre o caráter da luta por democracia em países capitalistas dependentes como o Brasil, sobre a construção de um partido revolucionário em meio a tais disputas. A polêmica estava apenas começando, e ganharia cores mais fortes nos números seguintes de Brasil Socialista. 


\title{
Enigmas da democracia, dilemas da esquerda
}

No editorial do terceiro número da revista, que foi publicado em julho de 1975, reaparecia a censura ao fechamento dogmático e à incapacidade de certos grupos de esquerda (mais uma vez sem identificação) de conectar-se à movimentação concreta das massas:

\begin{abstract}
Somente se nos ligamos estreitamente às lutas reais e vivas da classe operária e do povo, se somos capazes de interpretar corretamente os problemas que vão sendo colocados pela luta e se sabemos dar-lhes justas respostas, podemos dar passos efetivos [...]. Enganam-se lamentavelmente os camaradas que pensam em formar bases partidárias unicamente através $\mathrm{da}$ propaganda do marxismo-leninismo e dos princípios mais gerais da Revolução Socialista. Sem uma tática e uma linha de massas adequada, nossa propaganda hoje será estéril e restrita [...] (BRASIL SOCIALISTA, 1975c, p. 3)
\end{abstract}

Tática, não por acaso, era o tema do artigo de Raul Villa (VILLA, 1975b). O autor (trata-se do codinome de Eder Sader) era um importante dirigente da POLOP e havia sido identificado antes como representante da OCML junto à revista, mas a situação se alterava completamente agora. Desligado da organização desde 1972, sua condição de representante estava fundada em bases frágeis que foram definitivamente rompidas pelas divergências políticas que cresciam nas páginas de Brasil Socialista. ${ }^{2}$ Sua reflexão sobre a tática da esquerda revolucionária punha a nu alguns dos pontos de atrito.

Para ele, dificuldades opostas e simétricas com a tática aparecem nos dois polos da esquerda: enquanto os partidos reformistas tratavam a tática "ao modo burguês", negando na prática os objetivos estratégicos sempre afirmados em seus documentos oficiais, a jovem esquerda revolucionária, especialmente a latino-americana, influenciada pela revolução cubana e constituída por militantes de origem pequeno-burguesa, "[...] tendeu a saltar da estratégia global para a ação imediata”. Esta seria a origem de graves desvios dos grupos revolucionários: o "vanguardismo", típico de grupos armados que se lançaram em "ações exemplares”, acreditando que chegariam, assim, a dirigir o povo em sua luta contra seus inimigos históricos, e o "dogmatismo", pelo qual um punhado de doutrinadores pensa avançar em seus objetivos estratégicos ao lançar suas pregações teóricas e denúncias contra o oportunismo de outros grupos de esquerda.

Villa também interpretava o projeto de "institucionalização" como iniciativa do regime diante da crise que quebrava a coesão das classes dominantes, mas entendia que a tática da esquerda deveria ser a de "[...] responder levantando a bandeira da derrubada da ditadura militar." (VILLA, 1975b, p. 8). Em aberta divergência com a linha da OCML, sua abordagem do problema do enfrentamento da ditadura incluía a luta pelas liberdades democráticas:

Propugnando a luta pela conquista dos direitos democráticos - as liberdades políticas e sindicais, de organização e expressão em primeiro lugar - estaremos centrando o fogo no sistema de dominação política atual da burguesia e desmistificando a estreiteza dos programas democráticos das oposiçôes burguesas que arengam sobre democracia e 'fecham publicamente os olhos' para a existência de um aparato repressivo que garante a opressão das massas. (VILLA, 1975 b, p. 8) 
Rompido com a POLOP, Villa não apagaria de suas análises a influência de algumas das teses que tinha ajudado a desenvolver por tanto tempo. Mantendo alto o tom da crítica à oposição burguesa que já aparecia em seu artigo de janeiro, ele ultrapassava as análises da APML e se diferenciava da tática de alianças com a pequena burguesia democrática representada pelos "autênticos”. O objetivo de sua tática não era viabilizar uma etapa em que, garantidas as liberdades mínimas, fosse possível acumular forças. A luta pelas liberdades democráticas era o modo concreto de fazer a política revolucionária nas condições dadas e, partindo delas, de avançar na construção da organização revolucionária - meta perseguida unanimemente por toda a Tendência Proletária:

Ao mobilizar as massas hoje na luta contra o atual sistema de dominação burguesa, desenvolveremos a forma social capaz de passar dessa luta à destruição de toda e qualquer dominação burguesa no país. [...]. Ao colocar a plataforma de lutas pelas liberdades democráticas, contra a superexploração e pela defesa das condiçóes de vida das massas, contra a ditadura militar, estamos adequando a luta contra a exploração econômica e a opressão ao período atual. (Idem, Ibidem, p. 24, grifos do autor)

Ao endossar a luta pelas liberdades democráticas, Villa opunha-se à OCML, mas ao considerá-la uma "plataforma de lutas" ativadora de uma "[...] forma social capaz de passar dessa luta à destruição de toda e qualquer dominação burguesa [...]”, ele não se enquadrava facilmente na classificação de "reformista" e "populista" formulada por seus ex-companheiros. Sem qualquer menção a alianças, sua perspectiva era de que, aproveitando as brechas criadas pela crise, a força social construída pela esquerda proletária fosse

[...] capaz de neutralizar a oposição burguesa e arrastar sua base popular. Para isso ela levanta a bandeira da derrubada da ditadura militar e desenvolve uma plataforma de lutas concretas contra cada manifestação da opressão política e da opressão econômica; ela mantem a propaganda do socialismo que mostra às massas as causas reais da sua situação; ela impulsiona a organização das bases classistas sem as quais nenhuma política se mantem. (Idem, Ibidem, p. 25)

Raul Villa e os editores da revista estavam cientes de que as divergências com a OCML tinham ido longe demais. Uma correspondência enviada pela direção da P.O. aos editores e publicada neste mesmo número da revista revelou a profundidade da ruptura que se abria a partir do problema da luta pelas liberdades democráticas. Se a crise impunha à classe dominante a necessidade de desembarcar da ditadura, a POLOP entendia que uma política pela redemocratização significaria pedir ao proletariado que "tirasse as castanhas do fogo" para a burguesia. Nada havia mudado na relação de classes que pudesse justificar uma mudança na política da esquerda revolucionária, como queriam fazer a AP e o MR-8. Ao contrário, num país em que

[...] a revolução burguesa não está mais na ordem do dia, onde a 'revolução será socialista ou não será revolução', o proletariado só terá consciência de classe quando educado em torno de metas finais da sua luta, quando oposto a todas as formas de ditadura burguesa, também à democrática. (POLÍTICA OPERÁRIA, 1975b, p. 87, grifos do autor)

A POLOP trabalhava, desde o final da década de 1960, com a caracterização do regime militar como ditadura aberta e indireta da burguesia, diferente da situação anterior a 1964 que era de ditadura velada (pois tinha a forma de democracia), mas exercida diretamente pelos representantes da classe. ${ }^{3}$ Daí 
sua recusa a participar de movimentos amplos de combate à ditadura, já que eles silenciavam quanto ao caráter de classe do regime e de seu eventual substituto e, mais grave, deslocavam o foco da luta política para objetivos que não eram os do proletariado. Mantidas as posiçôes em defesa das liberdades democráticas, o projeto de fusão entre as correntes da Tendência Proletária “[...] só poderia ser realizado sob o preço do abandono de posições fundamentais da Organização" (POLÍTICA OPERÁRIA, 1975b, p. 68).

Eram posições que a POLOP defendia também perante um público mais amplo, através de seu jornal, o Politica Operária, distribuído em alguns pontos do Brasil, nos quais a organização dispunha de militância ativa: o "[...] movimento pela redemocratização nada tinha de revolucionário, porque não estava subordinado à tarefa de emancipar o trabalho do jugo do capital, ou seja, porque não se subordinava a uma estratégia proletária” (POLÍTICA OPERÁRIA, 1975c, p. 3). Lutas parciais em defesa da liberdade de manifestação e de organização, contra o arrocho salarial ou pelo direito de greve eram necessárias, mas sem se confundir com a bandeira pelas "liberdades democráticas” que os "populistas” consideram

[...] capaz de unificar os interesses de diferentes classes dispostas a lutar contra a ditadura. Nós os combatemos e os desmascaramos: se é certo que esta plataforma poderá futuramente unificar as lutas, será então uma unificação em torno de uma direção ideológica pequeno -burguesa. (Idem, Ibidem, p. 4)

O que a POLOP tinha a propor como tática decorria de uma avaliação da conjuntura que só ela fazia. Apesar de haver sinais de que segmentos da classe trabalhadora começavam a se mover, predominaria, ainda, a condição de isolamento e o caráter parcial daquela movimentação. Este seria um dado da luta de classes cuja modificação não poderia ocorrer por efeito de ações voluntaristas da vanguarda socialista, mas somente com o enfraquecimento político da burguesia que, embora tendente a se aprofundar com a crise, obedecia a ritmos que a esquerda não podia controlar. Enquanto perdurasse tal situação objetiva, não haveria espaço concreto para aproximar a vanguarda revolucionária das massas trabalhadoras e, portanto, o objetivo tático teria de ser outro, bem mais limitado: "Acumular forças ao nível das parcelas avançadas do MO [movimento operário] [...] de modo a organizar as bases futuras de um movimento operário independente" (Idem, Ibidem, p. 5). Uma perspectiva muito diferente do que propunham as correntes que permaneciam na Tendência Proletária.

Brasil Socialista seguiria adiante sem a OCML. Em outubro, no editorial do número 4, foi reiterada a linha política já traçada em abril: combater a “institucionalização” de Geisel e Golbery e aprofundar o isolamento da ditadura atraindo a pequena burguesia democrática na luta pelas liberdades políticas, unir os trabalhadores na luta por democracia e em defesa de seu nível de vida e fazer essas lutas convergirem para a derrubada da ditadura e liquidação de suas bases de sustentação (BRASIL SOCIALISTA, 1975d). As reaçôes da POLOP, no entanto, ainda incomodavam a ponto de motivar um longo artigo de Daniel Terra, dirigente do MR- 8 inteiramente dedicado a combatê-las. ${ }^{4}$ Diante de um cenário visto como mais favorável, com reanimação no movimento de massas, crise econômica e fissuras no bloco dominante, a passagem de setores da pequena burguesia para a oposição aberta à ditadura seria, para ele, a confirmação do "acerto tático" da esquerda revolucionária. A construção da direção política capaz de influir no movimento, contudo, encontrava-se atrasada e prejudicada pelas posições defendidas pela P.O. no interior da Tendência Proletária. Seu artigo, então, combate o "doutrinarismo e o economicismo" daquelas posiçóes, limpando o terreno para a formulação correta de uma "tática proletária de combate à ditadura” (TERRA, 1975). 
"Marxista vulgar", segundo Daniel Terra, a linha política da P.O. consistiria em aguardar até que a crise dissolvesse os elos políticos da classe dominante e despertasse a classe trabalhadora para só então lançar-se ao trabalho de aproximação com as massas. Puro "economicismo", semelhante ao economicismo russo, esta política "constitui uma fuga e uma capitulação em relação à principal tarefa dos comunistas no momento atual”, silencia quanto à tática e salta para o doutrinarismo abstrato (TERRA, 1975, p. 6). Dentre outros erros teóricos graves, a P.O. equivocar-se-ia ao supor que a democratização seria um programa bancado por todos os segmentos burgueses diante da crise, inclusive o grande capital e seus sócios imperialistas que, ao contrário, continuam a ser a base social do regime. Pior ainda, ela "confunde - de modo insultuoso e intrigante - como apoio ao 'movimento burguês pela redemocratização' o 'centro tático democrático' definido, de uma ou outra forma, pela grande maioria da esquerda proletária - que é na verdade o único caminho capaz de levar à desmoralização daquele movimento" (Idem, Ibidem, p. 24).

Lenin e principalmente Stalin são citados com frequência no texto que reafirma a linha política do MR-8 aprovada em 1972, segundo a qual o "centro tático político geral capaz de expressar os objetivos táticos para o momento coloca-se nas lutas democráticas, anti-ditadura e anti-imperialista." Expressão de um "momento de defensiva”, esse centro tático fixa o "ponto de partida para se iniciar um processo de inversão da atual correlação de forças" (Idem, Ibidem, p. 24). Stalin recomendava atacar pelo ponto mais frágil do inimigo e o ponto mais vulnerável do regime é seu aspecto ditatorial. Não há contradição entre a estratégia socialista e a tática de "aprofundamento e ampliação da democracia” porque

[...] antes que o proletariado tenha condições de partir para açóes mais vigorosas, antes que possa fazer balançar concretamente toda a estrutura de dominação, será preciso que já tenha conquistado uma série de posições, que já tenha conquistado uma margem maior de manobras, sem o que não poderá nem pensar em revolução aberta. (TERRA, 1975, p. 25)

Assim como a luta econômica e sindical não visa a organizar uma economia socialista, as “[...] lutas pelas liberdades políticas não alcançam de imediato a democracia proletária, embora ampliem a capacidade de manobra das classes revolucionárias" (TERRA 1975, p. 25). Por isso, participar das eleições de 1974 em aliança com a pequena burguesia democrática tinha sido acertado. A percepção correta das massas sobre o "mito parlamentar" não seria alcançada por doutrinação, mas por sua própria experiência que é acelerada pela presença dos comunistas nos espaços eleitorais denunciando e desvelando o mito.

Mais uma vez a autoridade de Lenin foi convocada, dessa vez para reafirmar a necessidade de participação nas eleições e em parlamentos mesmo que dominados por forças conservadoras. Daniel Terra reconhece que Lenin condicionava a participação de revolucionários em eleições à preservação da sua autonomia política. Ora, a campanha em torno de candidatos do "grupo autêntico" tornou a Tendência Proletária capaz de "[...] denunciar, mesmo sob as condições de ditadura, todo o caráter do atual regime, caráter de defesa do grande capital e massacre dos assalariados, de ter denunciado as traições dos 'liberais', de ter indicado o caminho de luta nas fábricas e nos bairros" (Idem, Ibidem, p. 32). Além do mais, seria imprescindível distinguir entre frentes eleitorais, constituída por alianças, e o partido revolucionário. A P.O. erraria novamente ao estender às frentes as restrições que Lenin e Marx formularam somente para os partidos. 
Omissa diante das massas, restrita à propaganda voltada para as "parcelas avançadas” do proletariado, apegada ao dogma do voto nulo quando as massas se movimentavam no campo oposicionista, indiferente à luta eleitoral e parlamentar e à conquista de liberdades democráticas, tudo isso "[...] reafirma que a P.O desdenha todas as alternativas de luta propostas pelas demais correntes da Esquerda Revolucionária não porque tenha uma melhor, mas justamente porque prefere o descompromisso com a luta”. Uma das últimas seções do texto ironiza o nome da corrente: "Organização de combate?" (Idem, Ibidem, p. 36).

O rompimento entre a revista e a OCML-PO era definitivo e foi anunciado oficialmente no editorial do número 5, de janeiro de 1976: “[...] consideramos que cometemos um erro de avaliação política ao colocarmos a P.O. como uma das forças mais avançadas da esquerda revolucionária”. A experiência de construção da Tendência Proletária mostrou que "[...] essa Organização tendeu a cristalizar-se em torno de seus desvios doutrinaristas e economicistas e, consequentemente, a se isolar frente ao movimento de massas" (BRASIL SOCIALISTA, 1976, p. 2). Do ponto de vista da P.O., a ruptura chegava com atraso e vinha para corrigir a "[...] situação esdrúxula na qual posiçóes políticas das mais duvidosas e nunca compartilhadas pela Política Operária do Brasil pudessem ser divulgadas em seu nome na Europa” (MARXISMO MILITANTE, 1975b, p. 2).5 Para os dirigentes da OCML, a APML e o MR8 é que teriam rompido a unidade anterior das três correntes em torno da avaliação da situação política e da posição frente às eleições: "Do Voto Nulo, nas eleições anteriores, passaram a apoiar a chapa do MDB, no último pleito [...]”, uma mudança baseada "numa avaliação teórica do papel da pequena-burguesia, diametralmente oposta às posições da PO.” (MARXISMO MILITANTE, 1975, p. 93).

A decisão de manter a tática eleitoral anterior não significava que a OCML subestimasse as mudanças de conjuntura. Ao contrário, a organização entendia que as "[...] tendências conjunturais apontam para uma crise nacional em todos os níveis [...]” e que as eleições de novembro do ano anterior deixavam à mostra a "quebra da precária unidade burguesa do período Garrastazu" (MARXISMO MILITANTE, 1975c, p. 6). Os resultados evidenciaram que o “[...] equilíbrio do bloco dominante vem sendo quebrado, e abre-se portanto a perspectiva de deslocamentos internos, ou seja, de uma reorganização da correlação de forças, entre as frações das classes dominantes”. O fim da ditadura está no horizonte, mas a burguesia permanece lutando por concessóes pontuais e aberturas limitadas. A política da classe dominante, todavia, tende a mudar no futuro próximo: quando à “[...] crise econômica e política (em agravamento) se juntar o dado concreto das mobilizações de massa - então a realidade será outra [...]. Ela terá então condições de se desfazer do regime militar, e recorrerá ao populismo como alternativa para controlar a situação.” (Idem, Ibidem, p. 8).

Para os que mantinham o propósito de construir a independência política do movimento operário, sem o que não avança o projeto revolucionário no Brasil, o risco de uma solução populista para a crise da ditadura era muito sério. A retomada do movimento terá de ser "uma mudança lenta, na medida em que o MO [movimento operário] aprenda, a partir da descoberta da própria experiência, que é possível avançar”. Daí a decisão de “[...] criticar com bastante ênfase o erro que vem sendo cometido por parte da ER [esquerda revolucionária], ao apoiar o movimento pequeno -burguês pela redemocratização. Abrindo mão da perspectiva de atuar na crise em marcha para lançar as bases de um MO independente.” (Idem, Ibidem, p. 9).

Em janeiro de 1976, a OCML publicou uma resposta mais extensa às críticas que lhe foram dirigidas em Brasil Socialista. Aqueles ataques seriam provenientes do retorno de "mitos pecebistas da redemocratização e da luta pelas liberdades democráticas”, ou seja, do "redespertar do reformismo". 
A APML e o MR-8, que "[...] vinham evoluindo no sentido de endossar a linha socialista e proletária [...] definiram-se publicamente por essa corrente democratista”. Elas é que fazem parecido com os economicistas russos, que "[...] deixavam a luta política a cargo dos outros; os nossos democratistas empunham diretamente eles próprios as bandeiras dos outros.” (MARXISMO MILITANTE, 1976, p. 10). Ao invés de preparar um "centro tático mais avançado", o MR-8 e a APML propóem atrelar o proletariado organizado ao parlamento burguês, a "[...] autênticos emedebistas e padres caridosos dando vivas ao habeas corpus enquanto uma burguesia zelosa e diligente estaria preparando seu novo matadouro" (Idem, Ibidem, p. 15). Levaria a "[...] um proletariado que ainda não tem consciência política, uma plataforma política pequeno-burguesa" (Idem, Ibidem, p. 16).

Para a P.O., seria um equívoco acreditar, como o MR-8, que a ditadura militar era um projeto apenas do grande capital, enquanto os setores médios defendem o liberalismo. Trata-se de uma visão "economicista e ilude o fato da hegemonia do grande capital no bloco dominante", pois o “[...] capital médio também sustentou a ditadura militar”. Posta a crise da ditadura, a “[...] alternativa do liberalismo aparece no horizonte como solução provisória para o conjunto do bloco dominante e não apenas para o capital médio" (Idem, Ibidem, p. 23). Procurando um mínimo denominador comum capaz de aproximar o médio capital e adjacências do bloco revolucionário, eles é que trocariam o bloco revolucionário pelas adjacências da classe dominante, indo, assim, assumir as reivindicações pequeno-burguesas típicas:

[...] contra o AI-5, contra as torturas, pelo 'habeas corpus', pelo livre funcionamento das organizações e partidos políticos, por eleiçóes diretas (!!), por igual acesso de todos os partidos aos meios de comunicação de massa (!!!), etc. [...] A luta contra a ditadura é muito bem explicitada - trata-se de luta pelas liberdades democráticas - superando inclusive indefinições sob as quais se escondia o caráter pequeno burguês do 'movimento contra a ditadura', proposto pela AP em 1965” (MARXISMO MILITANTE, 1976, p. 17).

Para a esquerda revolucionária, ao contrário, a tarefa que deveria comandar a tática desde o AI-5 era acumular forças "ao nível das camadas mais conscientes”. As palavras de ordem deveriam ser "contra o arrocho salarial, pelo direito de greve, pelo sindicato livre e pela liberdade de organização e de manifestação para a classe operária”. Era uma plataforma de lutas, não de "propaganda", como acusavam os críticos. A alternativa proletária, cuja possibilidade ainda não se materializara na conjuntura, abria-se na direção oposta à que era trilhada pelo democratismo reformista: “[...] a única alternativa revolucionária à ditadura militar é o governo dos trabalhadores, e não as liberdades democráticas” (Idem, Ibidem, p. 17). A insinuação de Daniel Terra de que a PO rejeita os métodos democráticos mostraria que ele "[...] toma aqui a democracia como conceito universal e neutro; e coloca a democracia que propóe para já como se fosse - usando a sua linguagem - a própria verdadeira democracia” (Idem, Ibidem, p. 22).

Era o aprofundamento e a radicalização da divisão. Os anos iniciais do governo Geisel impuseram à esquerda a definição de posiçóes a respeito da agenda de “distensão" e da movimentação das forças políticas de oposição. Demarcadas as posições, as organizações seguiram suas trajetórias. $\mathrm{O}$ escopo inicial da Tendência Proletária não se manteve. MR-8 e APML prosseguiriam juntos, por algum tempo, na editoria de Brasil Socialista, enquanto a OCML-PO marcharia em raia própria. Não foi a primeira nem a última vez que divergências a respeito da conjuntura levaram a rupturas e afastamentos entre grupos de esquerda - na verdade, este é um fenômeno recorrente ao longo 
de toda a história da esquerda, embora também aconteçam movimentos de aproximação e aliança que, possivelmente, repercutem menos. No entanto, o que acabamos de observar envolve mais do que uma discussão sobre as alternativas táticas a serem consideradas pela esquerda revolucionária para responder à conjuntura. $\mathrm{O}$ debate a respeito da democracia, tema inevitável e urgente no ocaso da ditadura e recorrente na história do país, abria questóes que iam mais fundo, no núcleo da estratégia revolucionária daquelas organizações.

O conhecimento do passado não entrega receitas para enfrentar os dilemas do presente, mesmo quando no presente nos defrontamos com problemas que atravessam o tempo, como é o caso da instabilidade crônica da democracia no Brasil. Contudo, os historiadores adotam a premissa de que conhecer o passado faz diferença no presente - se não fosse assim, aliás, como justificar a nossa profissão? O modo como os grupos de esquerda que estudamos aqui formularam o problema da democracia e as respostas que postularam não precisam ser lidas com a intenção de encontrar modelos ainda válidos ou úteis, mas ao conhecer aquela história ampliamos nosso repertório de referências a partir das quais elaborar nossa própria abordagem do problema. Porque a democracia continua a ser, para os contemporâneos, um desafio aberto.

\section{Referências}

ALMEIDA, Fabio de. Eleições: o voto e suas repercussões. Brasil Socialista. Le Mont (Suiça), [s.e.], n. 2, abr. 1975. p. 4-22.

APML. Na denúncia da farsa eleitoral, ampliar a resistência à ditadura. Brasil Socialista. Le Mont, [s.e.], n. 2, abr. 1975. p. 52-65.

BRASIL SOCIALISTA. Editorial. Brasil Socialista. Le Mont (Suíça), [s.e.], n. 1, jan. 1975a. p. 1-3.

BRASIL SOCIALISTA. Editorial. Brasil Socialista. Le Mont (Suíça), [s.e.], n. 2, abr. 1975b. p. 1-3.

BRASIL SOCIALISTA. Editorial. Brasil Socialista. Le Mont (Suíça), [s.e.], n. 3, jul. 1975c. p. 1-3.

BRASIL SOCIALISTA. Editorial. Brasil Socialista. Le Mont (Suíça), [s.e.], n. 4, set. 1975d. p. 1-3.

BRASIL SOCIALISTA. Editorial. Brasil Socialista. Ano II. Le Mont (Suíça), [s.e.], n. 5, jan. 1976. p. 1-3.

BRITO, Tamires Assad Nery. A Grande Tarefa: Política Operária e a Construção do Partido Revolucionário (1968-1979). Dissertação (Mestrado em História), PGH, Universidade Estadual de Feira de Santana. Feira de Santana, 2016.

COELHO, Eurelino. Dissonâncias à Esquerda: a POLOP, o Golpe e a Ditadura Militar. In: MATTOS, Marcelo Badaró; VEGA, Rubén (orgs.). Trabalhadores e ditaduras: Brasil, Espanha e Portugal. Rio de Janeiro: Consequência, 2014. p. 193-222.

DIAS, Reginaldo B. A cruz, a foice o martelo e a estrela: a tradição e renovação da esquerda na experiência da Ação Popular. Assis. Tese (Doutorado em História). FCL, Unesp, 2004

FERNANDES, Florestan. A Revolução Burguesa no Brasil. Rio de Janeiro: Zahar, 1975.

FERREIRA, Jorge; REIS, Daniel Aarão. As Esquerdas no Brasil. Rio de Janeiro: Civilização Brasileira, vol. 3, 2007.

FONTES, Virgínia. O Brasil e o Capital-Imperialismo. Rio de Janeiro: EPSJV: UFRJ, 2010. 
GEISEL, Ernesto. Pronunciamento feito na primeira reunião ministerial. Biblioteca da Presidência da República. Disponível em: http://www.biblioteca.presidencia.gov.br/presidencia/ex-presidentes/ernesto-geisel/ discursos/1974/03.pdf\#acontent. Acesso em: 25 abr. 2018.

GRABOIS, Mario Almada. A Luta Desarmada: a Esquerda Revolucionária e o debate da questão democrática nos anos 1970. Dissertação (Mestrado em Ciência Política). Universidade Federal do Rio de Janeiro, Rio de Janeiro, 2007.

HOLANDA, Sérgio Buarque de. Raízes do Brasil. 17. ed. Rio de Janeiro: José Olympio, 1984.

LOPES, Carlos. Claudio Campos: profundo amor ao Brasil, à humanidade e à verdade, 2018. Disponível em: http://www.fundacaoclaudiocampos.com.br/biografia.html. Acesso em: 17 set. 2018.

LOPES, Rosalba. Luzes à Esquerda: partidos e organizações marxistas no Brasil e a democracia nos anos 1970. Democracia Socialista. São Paulo: Ed. Caetés, n. 1, dez. 2013. p. 101-128.

MARXISMO MILITANTE. À redação de BRASIL SOCIALISTA. Marxismo Militante, [s.I.] [s.e.], n. 3, 1975.

MARXISMO MILITANTE. Editorial. Marxismo Militante e o Momento Presente. Marxismo Militante [exterior], [s.I] [s.e.], n. 1, 1975b. p. 3-5.

MARXISMO MILITANTE. Perspectivas para a luta de classes no Brasil. Marxismo Militante [exterior], [s.I.], n.1, op. cit., 1975c. p. 6-12.

MARXISMO MILITANTE. Por uma Tática Proletária: resposta ao Democratismo. Marxismo Militante, n. 2, [s.I.] [s.e.], 1976. p. 9-23.

MR-8. Orientação para a prática. Fundo Gilberto Mathias, pasta 11, Arquivo Edgard Leuenroth, jan. 1971.

MR-8. Linha Política. In: REIS FILHO, Daniel Aarão; SÁ, Jair Ferreira. de. Imagens da Revolução. Rio de Janeiro: Marco Zero, 1985.

OLIVEIRA JÚNIOR, F. Paixão e revolução: capítulos sobre a história da AP. Recife. Tese (Doutorado em História). IFCH, Universidade Federal de Pernambuco, 2000.

POLÍTICA OPERÁRIA. A Conjuntura Nacional. Brasil Socialista. Le Mont (Suíça), [s.e.], n. 2, abr. 1975. p. 66-70.

POLÍTICA OPERÁRIA. Resolução - Política Operária. Brasil Socialista. Le Mont (Suíça), [s.e.], n. 3, jul. 1975 b. p. 67-89.

POLÍTICA OPERÁRIA. Editorial. A Luta Pelas Liberdades Democráticas e Nossa Alternativa. Política Operária, [s.I.] [s.e.], n. 42, maio 1975b. p. 3.

SACHS, Eric. Classe e Estado, Ditadura e Democracia. In: MIRANDA, Orlando; FALCON, Pery (orgs.). POLOP: uma Trajetória de Luta pela Organização Independente da Classe Operária do Brasil. Salvador: CVM, 2010 p. 73-85.

SANTOS, Theotonio dos. Socialismo ou Fascismo: o Dilema Latino-Americano e o Novo Caráter da Dependência. Coleção Pátria Grande. Santiago do Chile: Editora Insular, 1970.

STOTZ, Eduardo. A POLOP e as esquerdas no enfrentamento à ditadura militar. In: MIRANDA, Orlando; FALCON, Pery. (orgs.). POLOP: uma Trajetória de Luta pela Organização Independente da Classe Operária do Brasil. Salvador: CVM, 2010. p. 279-290.

TERRA, Daniel. Contra o doutrinarismo e o economicismo. Por uma tática proletária de combate à ditadura. Brasil Socialista. Le Mont (Suiç̧a), [s.e.], n. 4, out. 1975. p. 4-39.

VIANNA, Luiz Werneck. Liberalismo e Sindicato no Brasil. Rio de Janeiro: Paz e Terra, 1976.

VILLA, Raul. Projetos e contradições das classes dominantes. Brasil Socialista. Le Mont (Suíça), [s.e.], n.1, 1975. p. 4-15.

VILLA, Raul. Notas sobre a Tática. Brasil Socialista. Le Mont (Suíça), [s.e.], n. 3, jul. 1975b. p. 4-25. 


\section{Notas}

${ }^{1}$ Disponível em cópia digital (pdf) no Laboratório de História e Memória da Esquerda e das Lutas Sociais (LABELU-UEFS).

${ }^{2} \mathrm{O}$ modo como a OCML via a participação de Raul Villa como seu representante na revista e a decisão de romper aquele vínculo foram explicitados em publicação própria da organização num documento intitulado À redação de BRASIL SOCIALISTA (MARXISMO MILITANTE, 1975).

${ }^{3}$ A exposição detalhada dos conceitos foi feita por Érico Sachs em artigo que circulou em 1967, antes do IV Congresso da ORM-PO, e foi republicado há alguns anos (SACHS, 2010).

${ }^{4}$ Pseudônimo de Claudio Campos. Anos depois, o autor voltaria a caracterizar como nacional e democrática a revolução brasileira (1982) e a resgatar totalmente a imagem positiva de Stalin (LOPES, 2018). Tornou-se dirigente do PMDB até morrer, em maio de 2005.

${ }^{5} \mathrm{O}$ nome Marxismo Militante foi dado a pelos menos três periódicos distintos, um deles editado sob responsabilidade do POC. O que citamos neste ponto era editado por militantes exilados (o que explica a inclusão de "exterior" em sua referência) e, no mesmo período, editava-se no Brasil outra série.

Recebido em: 14/06/2019

Aprovado em: 10/04/2020 